The Historical foumal, 5I, 2 (2008), pp. 457-480 (C) 2008 Cambridge University Press doi:Io.Ior7/Soor8246Xo8oo678X Printed in the United Kingdom

\title{
THE BATTLE OF DETROIT AND ANTI-COMMUNISM IN THE DEPRESSION ERA*
}

\author{
ALEX GOODALL
}

University of York

\begin{abstract}
A B S T R A C T. This article is an exploration of Diego Rivera's visit to Detroit in 1932-3. It seeks to use his experiences, and in particular the spectacular popular reaction to the Detroit Industry murals he painted, as a prism for analysing varieties of anti-communism in Detroit in the depression era. The article argues that close relationships between private capitalists, most notably Henry Ford and a Mexican communist, expose contradictions in big business's use of anti-communism in the interwar period, and suggest that anticommunism was a more complicated phenomenon than simply a tool for the promotion of 'free enterprise'. Moreover, by comparing the public reaction to the artists' work with their original intent, it is possible to see how members of Detroit's society unconsciously used anti-communism to sublimate broader concerns over race and ethnicity, gender, politics, and religiosity in a region in the throes of profound social change. The article seeks to highlight elements of these latent anxieties and fears in order to show how anticommunism acted as a vessel for social debate.
\end{abstract}

Mexican artist Diego Rivera travelled with his wife and fellow artist, Frida Kahlo, to the United States in late I930. Following a series of commissions in California and a visit to New York, Rivera was engaged to paint a mural for the walls of the central courtyard of the Detroit Institute of Arts (DIA), on the theme of 'Detroit Industry'. The mural was paid for entirely by Edsel Ford, son of Henry Ford and appointed successor to the Ford empire, which had its two most important plants in greater Detroit. The murals remain the centrepiece of the DIA, and truthfully speaking the only piece of locally commissioned art capable of attracting visitors from around the world. ${ }^{1}$

From the initial commissioning until long after its completion, Detroit society was scandalized by the murals, and the outcry - which led to them nearly being

Department of History, University of York, Heslington, York, YOIo 5DD ag566@york.ac.uk

* I would like to express my thanks to those who have provided advice, comments, criticism, and support during the writing of this article: particularly Tony Badger, Andrew Hemingway, Emily Critchley, Pat Flack, and Robert Tombs and the anonymous reviewers of the Historical fournal.

${ }^{1}$ In terms of the murals' position in art history, I defer to Linda Bank Downs, Diego Rivera: the Detroit Industry murals (New York, 1999); Patrick Marnham, Dreaming with his eyes open: a life of Diego Rivera (London, 1998); Desmond Rochfort and Julia Engelhardt, The murals of Diego Rivera (London, I987). 
whitewashed, as well as stimulating record-breaking attendance figures at their unveiling - has given them a particular significance in the cultural history of the city. The murals were explicitly intended to be a commentary on Detroit society, so friends and enemies of Rivera alike studied the work for hidden messages that might lie within the allegorical images. Because of this, the Detroit Industry murals act as a prism for public attitudes toward communism in the midst of the depression, and testify to the contestations that lay at the core of America's response to it. ${ }^{2}$

Historians have acknowledged that there were a multiplicity of anticommunisms and a myriad of anti-communists. But most have traditionally preferred to focus on 'characteristically' anti-communist groups or ways of thinking rather than the public debates that made up most of its history. In the I950s and I96os, the first students of anti-radicalism, predominantly political and social scientists, focused on social typologies, following the lead of Theodor Adorno's The authoritarian personality. ${ }^{3}$ Subsequent historians rejected the antipopulist implications of much of this analysis, choosing instead to focus on party politics and elite manipulation. ${ }^{4}$ But the framework for debate remained largely the same: a concern with identifying normative anti-communist groups and explaining their behaviour through their material or psychological conditions or ambitions, rather than understanding communism as an issue in public debate with which different groups concerned themselves and understood in different ways.

By the I980s and I99os, with post-structuralism on the march throughout the historical world, a more encompassing analysis of anti-communism was overdue. Michael Heale's American anticommunism presented an encyclopaedic vision of anti-radical tendencies in America dating back at least to the nineteenth century that gave ample evidence of the diversity of anti-communism and its complex mechanics at a local level. He and other historians wrote local studies of anti-radical politics that testified to the richness of uses to which anti-radical ideas could be put and the variety of ways that anti-communist ideology stemming from the centre was received in the periphery. However, as Heale noted in a recent historiographical essay, this route of study has since received only 'fitful

${ }^{2}$ For the political context, see M.J. Heale, McCarthy's Americans: red scare politics in state and nation, I935-I965 (Basingstoke, I998).

${ }_{3}$ Theodor W. Adorno, The authoritarian personality (New York, I950); Daniel Bell, The radical right (New York, I964); Richard Hofstader, The paranoid style in American politics, and other essays (New York, I965); Seymour Martin Lipset and Earl Raab. The politics of unreason; right-wing extremist in America, I790-I970 (New York, I970).

4 Nelson Polsby, 'Towards an explanation of McCarthyism', Political Studies (October i96o); Earl Latham, The communist controversy in Washington: from the New Deal to McCarthy (Cambridge, MA, I966); David Caute, The great fear: the anti-communist purge under Truman and Eisenhower (London, I978); Mary S. McAuliffe, Crisis on the left: Cold War politics and American liberals, 1947-1954 (Amherst, 1978); Kenneth O'Reilly, Hoover and the un-Americans: the FBI, HUAC, and the Red Menace (Philadelphia, I983); Regin Schmidt, Red scare: FBI and the origins of anticommunism in the United States (Copenhagen, 200o). 
attention' from historians. ${ }^{5}$ Instead, the end of the Cold War saw the diversion of historical debate away from the study of American anti-communists altogether and towards the communists. In the post-Cold War era, the New Right has sought to establish the 'guilt' of specific Soviet spies beyond reasonable doubt and thus reassert the party's conspiratorial credentials. By extension, this diverted attention away from the anti-communists, rendering them (by extension) rational actors responding to a Soviet threat from within. ${ }^{6}$

Only recently have historians begun to refocus upon the contested nature of anti-communism, and recent books on the topic thus demonstrate far greater awareness of the breadth of anti-communist debate. Ellen Schrecker argues that 'there was not one, but many McCarthyisms, each with its own agenda and modus operandi'. Richard Gid Powers argues that 'the reality of American anticommunism was too complex ... to be captured by stereotypes'. Markku Ruotsila declares that there 'never was any such thing as the one actoranticommunism, a unified ideology - reaching for the one end point - end of communism, singly defined'. Schrecker characterizes the central dispute between anti-communists as of liberal versus conservative variants. Ruotsila largely agrees, though adds socialist anti-communism to the mix. Powers, by contrast, has distinguished between traditional 'countersubversive' anti-communists, and a 'new breed' of anti-communist activists that emerged in the I920s: labour leaders, disgruntled former communists, Jews, blacks, and Catholics. But each still tends to generalize about anti-communism in ways that fail to stand up to scrutiny. Schrecker, for example, prefers to discuss 'McCarthyism' over 'anticommunism', since her primary concern is with state-centred political repression, rather than other elements of US opposition to communism. On the other hand, Powers concludes that 'Anticommunism expressed the essential American determination to stand against attacks on human freedom and foster the growth of democracy throughout the world. ${ }^{, 7}$ In practice these binaries fail to capture the breadth of the political debates taking place, and in this sense have obscured the complexity of anti-communism even whilst paying lip-service to this very fact. Only Ruotsila has really examined the disputes amongst anti-communists as central to the

5 M.J. Heale, American anticommunism: combating the enemy within, I830-1970 (Baltimore, I990); Heale, McCarthy's Americans; Alan Brinkley, Voices of protest: Huey Long, Father Coughlin, and the Great Depression (New York, I982); Leo Ribuffo, The old Christian right: the Protestant far right from the Great Depression to the Cold War (Philadelphia, I983); M.J. Heale, "Beyond the "Age of McCarthy": anticommunism and the historians', in Melvyn Stokes, ed., The state of U.S. history (Oxford, 2002), p. I45.

${ }^{6}$ Harvey Klehr, John Earl Haynes, and Fridrikh Igorevich Firsov, The secret world of American communism (New Haven, I995); John Earl Haynes, Red scare or red menace? American communism and anticommunism in the Cold War era (Chicago, I996); Harvey Klehr, John Earl Haynes, and Kyrill M. Anderson, The Soviet world of American communism (New Haven, I998); John Earl Haynes and Harvey Klehr, Venona: decoding Soviet espionage in America (New Haven, 1999); Allen Weinstein and Alexander Vassiliev, The haunted wood: Soviet espionage in America - the Stalin era (New York, I999).

7 Ellen Schrecker, Many are the crimes: Mc Carthyism in America (Princeton, I998), p. xiv; Richard Gid Powers, Not without honor: the history of American anticommunism (New York, I995), pp. 67, 426; Markku Ruotsila, British and American anticommunism before the Cold War (London, 200I), p. xi. 
mechanics of anti-communism, and here too he perhaps goes too far in straightforwardly equating anti-communism with anti-collectivism.

By examining an event - the unveiling of the Rivera murals in Detroit - and the public debate that surrounded it, rather than a particular individual or grouping, this article seeks to underscore the limits of existing interpretations of anti-communism. The judgements that different anti-communists made about the Detroit Industry murals were alternately personal, political, ideological, religious, and aesthetic. Because they spoke to so many different modes of analysis, they varied wildly and they objected to wildly varying elements of Rivera's personality and creation. The fevered response and public debate, moreover, took place at a critical juncture in American history: when existing formations of American nationalism had been challenged by a social crisis of epic proportions, when fissures were opening between formerly co-operative anti-communist communities, and when many Americans were turning to radical movements to solve problems of mass unemployment and hunger. In their own way, responses to Rivera revealed the evolution of anti-communist thinking from the progressive world of the rg2os to the New Deal era and beyond.

The first section of this article explores the events that led Henry Ford into an unlikely friendship with Rivera. This relationship is significant in terms of the attitudes Rivera brought to the murals' construction, but also sheds light on Ford's own anti-communism: pro-business, anti-union, and anti-Semitic, yet not particularly anti-Soviet. This version of anti-communism can be downplayed by histories that focus only on the relationship between anti-communists and the international Communist Party, and fails to fit neatly into the binary distinctions established by many historians of anti-communism. The second section deals with the murals themselves, and the explosive reaction that marked their completion. Such an eruption of cultural criticism could not have come about had Rivera's murals not tapped into deeper anxieties. The third and fourth sections of the article show how, and with what consequences, these were expressed in different interpretations of artistic intent during what Rivera later took to calling 'The Battle of Detroit', and the implications of these interpretations for the general history of interwar anti-communism.

\section{I}

Diego Rivera and Frida Kahlo arrived in Detroit in April 1932, roughly halfway through an extended sojourn in the United States. In a fortuitous arrangement of circumstances, interest in Rivera had grown north of the border just as life in Mexico had become less comfortable. The artist was under attack from both left and right in his native country, accused respectively of disloyalty to the Comintern and to the increasingly anti-communist nation. ${ }^{8}$

${ }^{8}$ See Daniela Spenser, The impossible triangle: Mexico, Soviet Russia, and the United States in the Ig2os (London, I999). 
Perhaps most importantly, Rivera had been ejected from the Party in 1929 for a number of infringements later translated into the catch-all sin of Trotskyism. Although at the local level many Party activists continued to support and defend Rivera's work, loyal members and the Party hierarchy in both Mexico and the United States began to call Rivera a charlatan, a 'millionaire artist for the establishment'. ${ }^{9}$ In 1932, the Communist Party of the USA (CPUSA) printed a swingeing indictment of Rivera in the New Masses, describing a man 'who progressed from Picasso to Zapata, from Zapata to Lenin, only to falter at a critical moment, to desert the new-found line, and to plunge back into the sterility of middle-class concepts' ${ }^{10}$ From the outset, then, Rivera was a troublesome communist pariah to American anti-communists, since he was more often than not the target for abuse from the CPUSA itself.

Despite its vitriol, the Party's critique had some foundation. For a supposed Marxist revolutionary, Rivera was surprisingly comfortable with commissions from latter-day Medicis in the belly of the colossus of the North. During their trip, Rivera and Kahlo spent around six months in California, where Rivera created a spectacular fresco, Allegory of Califormia, for the San Francisco Stock Exchange. ${ }^{11}$ A retrospective at the newly completed Museum of Modern Art in New York was sponsored by the Rockefellers. The Ford Motor Company paid for the Detroit Industry murals. And after Detroit, Rivera returned to New York to paint a mural at the Rockefeller Center, though since it included a portrait of Lenin, his plutocratic sponsor blanched and it was famously destroyed before it was completed. In effect, the couple's grand tour was entirely funded by North American magnates. Rivera liked to see himself as something approaching an aesthetic guerrilla, bringing about revolution from within, but it is not hard to see this as a rather self-serving perspective.

It would not have appeared so hypocritical had Rivera not previously used his work to attack the Ford and Rockefeller families, and the world of high finance. In his Ministry of Education frescoes, completed I928, a scene entitled 'Wall Street Banquet' depicts caricatures of Ford, John D. Rockefeller, and J. P. Morgan sitting around a table consuming a meal of spaghetti-like ticker tape spilling from an adding machine on a serving dish. (The scene is juxtaposed with a homely depiction of humble poverty, 'Our Bread'.) The political statement continued on another panel, 'The Orgy'. In this, as Elizabeth Fuentes Rojas writes, 'North American capitalists try to seduce Señorita Mexico with alcohol,

${ }^{9}$ Andrew Hemingway, Artists on the left: American artists and the communist movement, $1926-1956$ (New Haven, 2000), p. 93; Desmond Rochfort, Mexican muralists: Orozco, Rivera, Siquieros (London, 1993), p. 123 .

${ }_{10}$ Robert Evans, 'Painting and politics: the case of Diego Rivera', in New Masses (Feb. 1932).

${ }^{11}$ Marnham, Dreaming, p. 249. The California visit occasioned similar anti-communist outrage to the Detroit scandal. See Elizabeth Fuentes Rojas, Diego Rivera en San Francisco (Mexico, I99I); Anthony W. Lee, Painting on the left: Diego Rivera, radical politics and San Francisco's public murals (Berkeley, 1999). 
separating her from Communist influence. ${ }^{12}$ When the time came for Rivera to be seduced with champagne, he found the experience to be a rather pleasant one.

Accepting money from the Ford family should have been particularly difficult. By the early I930s, Henry Ford's reputation as a ruthless and uncompromising industrial anti-communist was virtually unparalleled. Ford had used the prosperous years of the Ig2os to build up a dense network of industrial spies, heavies, former criminals, and overseers in his plants. Managed by the pugnacious gangster, Harry Bennett, the so-called Service Department did not flinch at using physical violence against labour organizers, including communists: some of the few who managed to make any headway in organizing Ford's plants before the New Deal. ${ }^{13}$ Moreover, under the pressure of a drastic decline in automobile sales in the early depression years - national production fell from around 5.3 million to $\mathrm{I} \cdot 3$ million units between 1929 and $193 \mathrm{I}$-Ford had fired tens of thousands of workers, but made only marginal commitments to their relief. ${ }^{14}$ The Communist Party in Detroit exploited opposition to Ford's industrial absolutism to swell its ranks. ${ }^{15}$ The Daily Worker reported that the largest membership in the country was in Detroit, perhaps a thousand members, in part centred on the industrial Auto Workers Union (AWU) but mostly made up of unemployed workers. ${ }^{16}$

Events culminated in early March 1932, when several thousand people, led by communist organizers, marched on Ford's Highland Park plant. A resulting riot saw the loss of four lives and several hundred injuries. Many times the number of original protestors attended the funeral procession of the four activists a few days later, and the Internationale was sung at their graveside. In the public investigation that followed, Ford Motor Company used the presence of communists in the protests as justification for coercive tactics and a refusal to negotiate. ${ }^{17}$ Rivera came to Detroit only weeks after the fracas, delayed by a well-timed bout of influenza. The riot was at the forefront of public memory, and Rivera must have known of it. Nevertheless, Rivera took the commission, and the money.

Edsel Ford, Henry's son, had offered to pay Rivera what was then the princely sum of $\$ 2$ I, 000 to paint his murals at the DIA. ${ }^{18}$ Given that by 1932, under depression pressure, the budget for the Institute as a whole had fallen to $\$ 40,000$ - a tenth of its level four years earlier - the fee was enormous. ${ }^{19}$ Given

12 Rojas, Diego Rivera en San Francisco, p. I3. My translation.

13 On Ford, see Allan Nevins, Ford: the times, the man, the company (New York, I954); Allan Nevins and Frank Ernest Hill, Ford: decline and rebirth, I933-1962 (New York, I963). Bennett's story can be found in Harry Bennett, We never called him Henry (New York, I95I).

14 The Ford payroll fell from $\$$ I 8 I $\mathrm{m}$ to $\$ 35 \mathrm{~m}$ between 1929 and I933. Laurance P. Hurlburt, The Mexican muralists in the United States (Albuquerque, I989), p. I33.

$15 \mathrm{~J}$. R. Prickett, 'Communists and the communist issue in the American labor movement, I920-I950' (Ph.D. thesis, UCLA, I975), p. i I7.

16 Theodore Draper, American communism and Soviet Russia (New York, I960), p. I88.

17 For the CPUSA reaction, see Felix Morrow, 'Class war in Detroit', New Masses (May I932).

18 'Edsel Ford: artistic industrialist', The Dearborn Herald, 8 (Spring 1979).

19 Marnham, Dreaming, p. 256. 
the layoffs that were taking place at the Ford plant because of supposed financial pressures and the rioting that followed, it was scandalous.

Moreover, Rivera was a progressive-minded anti-chauvinist. Virtually his first action upon arriving in the city was to force his chosen hotel, the Wardell, to abandon its traditional policies of banning Jewish guests by pretending to be Jewish himself. ${ }^{20}$ Ford, by contrast, had distinguished himself in the I920s for a vicious and single-minded campaign of anti-Semitic propaganda. Using his pet newspaper, The Dearborn Independent, which dealers were obliged to sell on their forecourts, Henry Ford had propounded extremist views on the supposed menace of international Jewry. The campaign ultimately earned him a place of affection amongst the highest echelons of Nazi Germany, a medal of achievement from Hitler, and the 'honour' of being the only American mentioned in Mein Kampf. ${ }^{21}$ A series of law suits had forced him to make a public apology in the late I920s, but he continued privately to support anti-Semites throughout the I93os.

As part of this campaign, Ford had been the first to publish the Protocols of the Elders of Zion on American shores. Since these famous forgeries dealt in large part with plans to establish a Jewish world government, Ford's staff used it as a device for associating their Jewish enemies with Bolshevism, much as was done by fascist parties in Germany and elsewhere. The Soviet government was part of what Ford called, 'A nasty Orientalism [that] has insidiously affected every channel of expression.' '22 'The professional financiers wrecked Germany', Ford wrote in his I926 autobiography, Today and tomorrow. 'The professional reformers wrecked Russia. You can take your choice as to who made the better job of it. ${ }^{, 23}$ Ford, then, was widely known as an exponent of an aggressive set of ideologies that increasingly used fears of communism to justify hostility to both unions and Jews.

Given Henry Ford's profound anti-unionist and anti-Semitic anti-communism, one must ask how Rivera could have accepted money from the Ford Motor Company to work on a commission whilst still professing to be a revolutionary. At first, the explanation may appear to lie in the mediating influences of the peaceable Edsel Ford and the various representatives of the DIA (with whom Rivera did indeed get on well). But an examination of Rivera's first months in Detroit shows that he and Ford were not only associated via mutual acquaintances, but developed a close and affectionate regard for each other in a surprisingly brief period of time.

The theme of the murals was to be 'the Spirit of Detroit'. To Rivera, the spirit of Detroit, that most industrial of cities, lay hidden in its factories, the reason he had been so eager to travel to the city in the first place. Over three months, Rivera

${ }^{20}$ Ibid., p. 258; Hayden Herrera, Frida: a biography of Frida Kahlo (London, I998), p. I34.

21 Albert Lee, Henry Ford and the fews (New York, I980), p. I4. Also see Neil Baldwin, Henry Ford and the fews: the mass production of hate (New York, 200I).

${ }_{22}$ Ford, in collaboration with Samuel Crowther, My life and work (London, I924), p. 25I.

${ }^{23}$ Ford, in collaboration with Samuel Crowther, Today and tomorrow (London, I926), p. 24. 
proceeded to race from factory to factory across the greater Detroit area, making hundreds of sketches. He recalled, 'I studied industrial scenes by night as well as day ... [making sketches] of towering blast furnaces, serpentine conveyor belts, impressive scientific laboratories, busy assembling rooms; also of precision instruments, some of them massive yet delicate; and of the men who worked them all. ${ }^{24} \mathrm{He}$ visited dozens of locations around the city, but his chief inspiration came from the Ford company's River Rouge plant: the largest mechanized site of communal industrial activity in the world. ${ }^{25}$ The artist decided to focus his mural on the construction of Ford's new V8 engine. Different panels would reflect the various stages of mechanical production and assembly, from mineral ore in the soil to finished product, driving into the sunset. During his time researching the topic, Rivera visited Ford's museum of American antiquarianism in nearby Dearborn, which he found to be a 'visual feast', 'organized not only with scientific clarity but with impeccable, unpretentious good taste'. He dined with Ford, whom Rivera considered 'a charming man, old in years but in other ways very young', and had 'one of the most intelligent, clever and lively conversations I have ever enjoyed'. Over the course of the meal, the two discussed technology, mechanics, and the future, and the communist revolutionary took his leave after several hours, entirely won over by the capitalist millionaire. Ford said he believed the Mexican might be even more interested in mechanics than he: from Ford, high praise indeed. ${ }^{26}$ Rivera in return

[R] egretted that Henry Ford was a capitalist and one of the richest men on earth. I did not feel free to praise him as long and as loudly as I wanted to, since that would put me under the suspicion of sycophancy, of flattering the rich. Otherwise, I should have attempted to write a book presenting Henry Ford as I saw him, a true poet and artist, one of the greatest in the world. ${ }^{27}$

It was this shared faith in technology that brought capitalist and communist together. Rivera subscribed to the optimistic modernism written into communism since I848, which meshed with Ford's predictions for the future, expounded upon in publications like his autobiography Today and tomorrow. The artist shared Marx's enthusiasm for the achievements of bourgeois society when he talked about Detroit industry as a site of New World wonders, echoing the Communist manifesto's statement that the bourgeoisie 'has accomplished wonders far surpassing Egyptian pyramids, Roman aqueducts and Gothic cathedrals' ${ }^{28}$ Rivera's old friend Bertram Wolfe commented that it simply 'did not occur to Diego that the machine might also be used to extend the power of a dictator over the ruled ${ }^{29}$

\footnotetext{
24 Diego Rivera, My art, my life: an autobiography (New York, I99i), p. II . Henceforth MAML.

25 On artistic representations of the Ford plants, see Mary Jane Jacobs, Linda Downs et al., The Rouge (Detroit, I978). $\quad{ }^{26}$ Rivera, $M A M L$, pp. II2-I4. $\quad{ }^{27}$ Ibid., p. II5.

${ }_{28}$ Karl Marx, The communist manifesto (London, I998; first edn I848), p. 38.

29 Bertram D. Wolfe, The fabulous life of Diego Rivera (London, I968), p. 307.
} 
Friendship with Rivera highlights some of the greatest contradictions in Ford's blend of anti-communism and high modernist industrialism, a variant of anticommunism that fails to fit neatly into historically defined categories of 'liberal', 'conservative', 'counter-subversive', or 'new breed'. Despite his aggressive attacks on communism in his plants, and regular denunciation of international communism as the political phase of a world Zionist conspiracy, Ford expressed a quixotic respect for communism in Russia, and had been one of the first major industrialists to export industrial goods from the USA after the October Revolution. ${ }^{30}$ Dearborn Independent editor W. J. Cameron recollected in I952,

We all feel, I think, that the American Revolution is completing its circuit of the world and that it is manifesting through less well-prepared minds than it did with our forefathers, coming out in curious forms with the same spirit. Mr. Ford probably had the feeling in the beginning that this [Russian Revolution] was another as it looked then ... we were very glad to see the people step out. ${ }^{31}$

Like many American anti-communists in the depression years, Ford was inclined to look more favourably upon Stalin than his predecessors, arguing that communism in Russia was, by the later I920s, being diluted. In the middle of I925, the Dearborn Independent ran a report from a correspondent who had recently returned from a trade fair in Nizhny Novgorod. The reporter found communism transformed: 'Communism is very fine', he said, 'but money is what's needed right now.' A report in October I926 argued that Jewish groups were being thrown out of Russia. In November, a piece was published called 'Red Russia turns pink'. 'Under Stalin', it glowingly explained, Russia 'is leaving behind the doctrines of world revolution and pure Marxism ... [Stalin] has thrust aside at least temporarily the Jewish ideal of world revolution ... The defeat [of the Jews] augurs well for Russia. ${ }^{32}$

During the first Five Year Plan, Ford exported tens of thousands of cars, trucks, and tractors to Soviet Russia, and built a number of plants there. At the same time that he was attacking communists for leading unemployment demonstrations against his company, fifty to a hundred Soviet engineers were being trained at Highland Plant in the mechanics of automobile construction, to learn skills to take back to communist Russia. Anecdotal (and perhaps apocryphal) descriptions of the Hunger March rioting even place the area allocated to the Soviet engineers overlooking the scenes of violence. In a hagiographic biography of Ford, William Adams Simonds wrote of 'a great room in which were seventy Soviet engineers, learning to take back to Communist Russia what the American

30 Evidence suggests Ford was in negotiations with Soviet representatives as early as I9I9, whilst it was still illegal to export to Russia. See Edward Jay Epstein, Dossier: the secret history of Armand Hammer (London, I996); Joseph Finder, Red curtain (New York, I983); Mira Wilkins and Frank Ernest Hill, American business abroad: Ford on six continents (Detroit, I964).

31 Benson Ford Research Centre, Henry Ford Museum, Accession 65, Reminiscences of W. J. Cameron (Draft, I952), p. 26.

${ }^{32}$ Dearborn Independent, I3 June I925, pp. 4-5, 26 Oct. I926, p. I I, 6 Nov. I926, p. Iо. 
Communists were bent on destroying'. 'The Soviet engineers lined the window', Simonds claimed, "marvelling at what they called "the fools" in the road below. ${ }^{33}$

\section{I}

On 25 July 1932, Rivera began his work on the murals. His punishing goal was to complete twenty-seven large panels on the four walls of the Garden Room of the DIA in nine months: as demanding a schedule as any speedup set by Ford's plant managers. He had long been convinced that murals offered the best method for engaging art with the masses. He believed, as his compatriot and rival Orozco put it, that frescoes 'cannot be hidden away for the benefit of a certain privileged few' ${ }^{34}$ Rivera rejected the elitism of the European avant-garde and its complex, exclusive language, as well as the crudities and didacticism of Soviet-sponsored socialist realism. ${ }^{35}$ Yet he retained the flavour of a Mexican Constructivist, determined to use his artistic skills as a tool for social activism. ${ }^{36}$

Duly, the murals proved socially incandescent. In fact, the scandal had erupted before Detroit Industry had even been completed. It stemmed from a vituperative, and anonymous, letter to the editor of the Detroit Free Press, which complained that the officials of the DIA had paid Diego Rivera to paint murals which promoted communism. The press took up the baton, but religious leaders and bastions of society provided the most vocal and sustained outrage over the work. Leading the charge were the Methodist Episcopalians and the Catholics, most vocally the Rev. H. Ralph Higgins of St Paul's, and Father Charles Edward Coughlin. Coughlin was arguably the most famous Catholic priest in the United States by 1930, due to his syndicated weekly radio show that reached anything up to forty million Americans, which he quickly began to use to launch attacks against Rivera. Meanwhile, Reverend Higgins complained to the Free Press that Detroiters had been 'violently upset' by the paintings. A Monsignor Doyle (who had declined to see the frescoes personally) 'felt it was an affront to millions of Catholics that a man who was a Communist and an anti-clerical should have been given the commission, ${ }^{37}$

There were, however, as many complaints as there were varieties of anticommunism. Perhaps the most common criticism was a perceived vulgarity in the pictures, a sense of the painting's ugliness. ${ }^{38}$ Rivera himself said that the

\footnotetext{
33 William Adams Simonds, Henry Ford: a biography (London, I946), p. I93.

34 Cited in Rochfort, Mexican muralists, p. 8.

35 Alicia Azuela, 'Rivera and the concept of proletarian art', in Cynthia Newman Helms, ed., Diego Rivera: a retrospective (New York, I986), p. I25.

36 Biancamaria Tedeschini Lalli, "Art as a weapon" as a popular issue: Detroit's reception of Diego Rivera's murals', in Rob Kroes and Alessandro Portelli, eds., Social change and new modes of expression: the United States, I9IO-I930 (Amsterdam, I986), pp. 203-20.

37 Detroit Free Press, i7 Mar. I933.

38 See MacKinley Helm, Modern Mexican painters (New York, I94I), p. 54.
} 
four aboriginal figures crowning the north and south walls were 'hardly pretty'. ${ }^{39}$ Others objected to specific elements within the work. Some people found the depiction of industrial activity distasteful, and assumed the murals were highlighting poor workers' conditions. Mrs August Helbig of the Detroit Review Club felt that there was not 'a healthy-looking workingman among them. The men look sickly; over-worked, half-starved, dissatisfied. Whereas I have been in Detroit automobile factories and have been inspired by the fine-looking men at work there. ${ }^{, 40}$ An editorial in the Detroit Newes argued that the work was 'a slander to Detroit workingmen'. This was not a fair picture of the Detroit worker, 'who works short hours, who must be quick in action, alert of mind; who works in a factory where there is plenty of space for movement, where heavy burdens are borne by mechanical lifts and conveyors of many kinds, where there is good ventilation and light and ever facility to encourage efficient labor' ${ }^{41}$ Even Edmund Wilson described the workers as 'pinched and pallid worms... enmeshed in the metallic entrails of the conveyors'. ${ }^{2}$

Others considered the frescoes pornographic. The Free Press discreetly avoided explicit reference to the offensive content, but one assumes it was the large seminude figures that dominate the North and South walls. An art expert was called in to pass professional judgement: Eugene Paulus, formerly of Loyola University, felt that 'in a high school they wouldn't tolerate such a detailed sketch in the class books'. ${ }^{3}$ Still other opponents argued that the images reflected nothing of Detroit's spiritual life. In an interview, Rev. Higgins said

In the first place, these realistic [sic] murals are about as appropriate to the classical court of our art museum as a jazz band in a medieval cathedral ... The incongruity smites the visitor mightily; he is aware of a painful esthetic conflict between the antagonistic ideals typified ... In the second place, the murals presume to typify the spirit of Detroit. If the genius of our people be unmixed materialism and atheism, if our gods be science and sex, if the brutality of the machine age is the sole virtue which our fair city expresses, if these things be true, Mr. Rivera should be hailed as a modern Michael Angelo.

Perhaps the most vehement criticism related to the panel known as 'Vaccination'. The panel depicts a modernized nativity - Joseph in a white lab coat inoculating the child Jesus (a 'fat ugly child', Rev. Higgins concluded), and Three Wise Men looking through microscopes. It was widely seen as blasphemy. 'I do not consider myself to be squeamish', said the Reverend, 'but I must confess to a startling and unpleasant reaction to this particular panel. ${ }^{\mathbf{4 4}}$

Complaints continued after the official dedication on I8 March I933. What Bertram Wolfe called 'mutual-excitation societies' of the rich and powerful were hastily arranged to lobby for whitewashing. 'Beautiful, well-dressed ladies', Rivera remembered, 'complained about the loss of their peaceful, lovely garden,

\footnotetext{
39 Rivera, MAML, p. iा6. $\quad{ }^{\mathbf{4 0}}$ Detroit Free Press, 20 Mar. I933. $\quad{ }^{\mathbf{4 1}}$ Detroit Newes, i9 Mar. i933.

42 Cited in Lalli, "Art as a weapon",, p. 2I I. 43 Detroit Free Press, 2 I Mar. I933.

44 Ibid., I7 Mar. I933.
} 
which had been like an oasis in the industrial desert of Detroit.' Councilman William P. Bradley used budgetary hearings of the Detroit Common Council to 'deliver a fifteen-minute attack', calling the frescoes a 'travesty', 'caricatures which have offended thousands'. The murals, he argued, 'completely ignore the spiritual and cultural aspects of this city ... They do not touch on the educational advances of this city. Nor are they even representative of the industrial life of this city. ${ }^{45} \mathrm{He}$ proposed that the murals be whitewashed. Eugene Paulus 'claimed that a symbol representing the communist fist [had been] painted on the "taxpaid walls" of the institute'. 'Birth on the North American continent', Paulus opined, 'did not make [Rivera] an American in the commonly accepted sense of the term.' The same point was echoed by the editor of the Free Press: 'An art director is brought from Germany to commission a Mexican artist to interpret the spirit of an American city. Why not hire a French director to find us a Japanese muralist to tell us what he thinks we look like. ${ }^{, 46}$ On the same day, a letter from C. Austin Johnson said, 'I have devoted some 50 years to art ... there can be no other conclusion than that it is a joke in every detail.' More comically, one J. W. Lyons, who claimed he ought to be a 'pretty good judge of art because I am not an artist and also because I am color blind', called Rivera's work 'a disgrace from a technical point of view. Art must be beautiful.' George H. Derry, president of Marygrove College, concluded, 'Senor Rivera has perpetrated a heartless hoax on his capitalist employer, Edsel Ford. Rivera was engaged to interpret Detroit; he has foisted on Mr. Ford and the museum a Communist manifesto. ${ }^{.47}$

The clashes that took place over Rivera's murals were more than the artist could have dreamed of. A committee to defend the murals was organized, and supporters ranging from the shop floor to Edsel Ford's office appeared on radio and sent letters to the press to defend Rivera's work. Newspapers devoted pages to correspondence sent in from excited individuals. Edsel himself came out publicly to defend his investment. Ford's architect Albert Kahn, who had been won over to the project through his encounters with Rivera, said

There is nothing new in these attacks by churchmen. Michelangelo portrayed as devils the churchmen who tried to interfere with him when he was doing the Sistine Chapel. You can see their portraits today in the Sistine frescoes. Rembrandt was just as guilty of charges of sacrilege as Rivera. But who throws stones at Rembrandt today ? $^{48}$

Within a week, news had spread across the country. On one day alone, over Iо,000 people came to see the murals. Between 70,000 and I00,000 visitors saw the murals before the month was out. This quite unprecedented public interest in

${ }^{45}$ Detroit Newes, 2I Mar. 1933.

${ }^{46}$ Quoted in Hurlburt, Mexican muralists in the United States, p. I58.

${ }^{47}$ Wolfe, The fabulous life of Diego Rivera, p. 3 II ; Rivera, MAML, p. II9; Downs, The Detroit Industry murals, p. 175; Detroit Free Press, 21 Mar. 1933; Donald Lochbiler, 'Battle of the Garden Court', Detroit Newes, n.d., http://info.detnews.com/history/story/index.cfm?id $=\mathrm{I} 87 \&$ category $=$ locations $\quad[\mathrm{ac}-$ cessed in Apr. 2005].

${ }^{48}$ Downs, The Detroit Industry murals, p. 176. 
Detroit art seemed to confirm Rivera's belief that it was possible to create works that would not just comment on but change society.

The artist's view was confirmed emphatically, at least according to his recollection of the dénouement of what he now hubristically began to call 'the Battle of Detroit'. Rivera remembers being called out to the Institute upon the appearance of 200 workers. According to Rivera, the workers explained that they feared that counter-revolutionary enemies of the frescoes would try to whitewash the murals when no one was looking, so 8,0oo of them had volunteered to guard the room in shifts morning until night, until the scandal died down. They proceeded to check the names of every visitor to the Institute. Rivera recollected, 'Until all the sound and the fury had passed, my army of eight thousand, working in shifts, guarded my work from destruction'. ${ }^{49}$ Much of this is surely exaggeration, but Rivera was euphoric, convinced that this proved he had achieved his goal. $^{\mathbf{5 0}}$

\section{I I}

There can be little doubt that, to fans and detractors alike, the Detroit Industry murals were shocking and unusual. There can be little doubt, either, that the complaints against the murals came from all levels of society, and a wide range of religious and social groups. Rivera had certainly gone against the expectations of his audience. 'People looked for the statuesque female of classic drapes', Bertram Wolfe wrote, 'holding a tiny automobile in one hand and a lighted torch in the other. ${ }^{51}$ But despite Rivera's presumptions, there is little to suggest that the frescoes could have elicited such an explosive reaction had they not tapped into pre-existing sensitivities about communism in a city that was suffering some of the worst depredations of the depression era. Moreover, examination of the complaints reveals that many of the most vocal opponents of the Rivera murals were talking about the city and the country as much as the walls of the DIA.

Those who claimed that the work was taking Christianity in vain were probably justified. Rivera certainly felt that industry was the true god of Detroit, and subscribed to the official, anti-clerical doctrine of the Mexican revolution and Marxist Communism. Ambiguously, Rivera explained that the 'Vaccination' panel was 'intended to celebrate the noble work of men of science fighting against disease' ${ }^{52}$ To his anti-communist audience, though, the message was clearer: science would replace religion.

Nevertheless, Rivera's attitude toward religion was complicated, and he did not subscribe to a philosophy of pure materialism. Rivera's philosophy was

49 Rivera, MAML, p. I20. $\quad 50$ See also Rivera's comments in Detroit News, I9 Mar. I933.

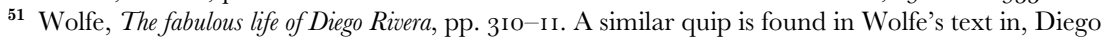
Rivera, Portrait of America (New York, I934), p. 52. Henceforth Rivera, POA.

${ }^{52}$ Rivera, $M A M L$, p. II7. 
not really the point, though. His murals stood in for other frustrations, including the anger felt by the Catholic church over policies pursued by the government of Mexico: especially the ban on public Catholic ceremonies that had led to the Cristero uprisings. Father Coughlin's recently completed church, on Twelve Mile Road, included a plaque depicting the execution of Father Miguel Agustin Pro, an art-deco echo of Manet's Execution of the Emperor Maximilian (I867). Coughlin had met Father Pro in the mid-twenties, before the Mexican priest returned home to become the most celebrated martyr of the Catholic uprising. Like other American anti-communists, Coughlin saw the anti-clericalism of the Russian and Mexican regimes as evidence of a common Bolshevik tendency, and ignored the rapid deterioration of relations that had taken place between the two countries during the twenties, and the recent attacks by the Mexican government on the Mexican Communist Party. ${ }^{53}$ As with the Mexican and Russian governments, so too with the Detroit Industry murals: distinctions between Rivera and the government of the country he came from were obscured behind a red mist.

Frustrations about materialism spoke to Detroit residents more widely than simply in terms of Mexican politics, though. In the first decades of the twentieth century, Detroit's churches had been closely aligned with the powerful business interests that were dominant in Michigan. But tensions had emerged in the late twenties, as conditions for workers of all faiths declined and some religious leaders felt a pressing need to speak out. Industrial society had contributed, amongst other things, to widespread poverty, overcrowding, crime, and divorce, and radicals amongst all the main churches began to fear that the religious duty to challenge injustice was being compromised by a too-close alliance with the wealthy of Detroit. A minor scandal had broken out in I926, when the business community had put intense pressure upon Detroit's churches to bar American Federation of Labor representatives access to the pulpit. A young Reinhold Niebuhr and the Unitarian churches were amongst the few who resisted the power of Detroit's monied establishment to allow labour representatives access to their parishioners. Niebuhr later recollected: 'The business community of Detroit, which had always breathed sweetness and light, showed its fangs.' The Chamber of Commerce 'shrewdly sent committees that would be most influential in each particular church situation to the pastor and to the board members to ask for the withdrawal of these invitations'. Under this pressure, all of the churches, with the aforementioned exceptions, 'withdrew their invitations in a rather abject way'.54

Although it does not appear so at first, Coughlin spoke to these class-based frustrations when he attacked Rivera's 'godless communism'. The radio priest, who had been a controversial and public supporter of Roosevelt in I932, mixed

\footnotetext{
53 For example, Francis McCullagh, Red Mexico (New York, I928).

54 Reminiscences of Reinhold Niebuhr (1953), Columbia Oral History Project, Columbia University, pp. $28-9$.
} 
nineteenth-century Populism with the rhetoric of the Rerum Novarum. He took to the radio in imitation of the muckraking Detroit journalist Jerry Buckley, who had been murdered by gangsters in I930 for speaking out against political corruption during the notorious mayoralty of Chester Bowles. Coughlin argued that the unmediated power of big business and unfettered use of private property had led to the great sins of modernity, including communism and atheism, by exploiting workers and removing their stake in society. Incoherent about the precise mechanics of this relationship, he even implied that businessmen and communists were in cahoots: with hindsight an absurd accusation, but perhaps not so strange to people at the time, given Henry Ford's forays into Soviet Russia. In a public hearing on communism in Detroit in 1931, Coughlin had predicted a revolution in the United States by I933, and blamed it squarely on the 'international industrialism' of Henry Ford. ${ }^{55}$ The relationship between the Ford company and Rivera seemed to prove what was otherwise a fairly tendentious argument. So, even though religious attacks on Rivera's work seem to be wholly conservative, we can also see the radical implications of the same fear of godlessness, when it depicted unfettered capitalism and international communism as part of the same modernistic tendencies rejecting God and God's teachings. Coughlin's anti-communism was thus as distinctive as Ford's, more appropriately seen as 'populist' than 'conservative' or 'liberal', but in truth struggled to fit even in that category.

If there was some foundation to allegations of blasphemy, other criticisms of Rivera's work were less accurate. It was certainly unfair to suggest that the frescoes were derogatory about Detroit industry, as Mrs August Helbig had complained. Rivera's enthusiasm for the city's mechanical heart has already been noted, and can easily be recognized in his depiction of clean, safe, and healthy factory floors.

Rivera was vocal about his identification with the worker and his struggles; he routinely described himself as a worker and said his audience was the proletarian mass. His reason for coming to the United States, he wrote, was to test 'the action and reaction between my painting and great masses of industrial workers ${ }^{56}$ But, fundamentally, the Detroit Industry murals stress the universal and the harmonic over the particular and the troubled. With a great leap of logic, Rivera contended that since a machine was 'planned in immediate and direct relation to its function ... [it] must have been constructed under inevitably harmonic conditions ${ }^{57}$

The motifs that run through the murals in particular reference Aztec cosmology and cyclical processes more generally. The murals are designed to be viewed in rotation, and stress the transformative processes of creation and

55 On Coughlin's changeable relations with Ford, see Charles J. Tull, Father Coughlin and the New Deal (New York, 1965); Sheldon Marcus, Father Coughlin: the tumultuous life of the priest of the Little Flower (Boston, I973); Brinkley, Voices of protest; Donald Warren, Radio priest: Charles Coughlin, the father of hate radio (New York, 1996).

${ }^{56}$ Rivera, $P O A$, p. I3.

${ }^{57}$ Ibid., p. I8. 
destruction that underpin life. ${ }^{58}$ Dualisms thus recur: life and death, war and peace, and so on. Warplanes and poison gas contrast inoculations and passenger aeroplanes, a dove of peace faces a hawk of war. But Rivera's interest in the unity of man and machine, and desire to depict an idealized view of technology, rather than the Rouge plant itself, meant that he was unable or unwilling to stress poor conditions, short-term privations, or immediate hardship. The workers hardly appear to be straining under their physical labour; their co-ordinated action appears 'not so much a toil as a dance'. ${ }^{59}$ Outside observers who have come to assess factory conditions are mocked as gawping prigs, self-righteous priests, and bored schoolboys: figures of 'society', enjoying the benefits of, but essentially separate from, the reality of America's industrial democracy. As Desmond Rochfort writes, '[Rivera] painted men and machines as a gigantic symphony, a harmonious synthesis of human and mechanical action, which together represented a potential creative power unparalleled in history. ${ }^{, 60}$

The response to a criticism never made is evidence of the sensitivity felt by Detroiters who owed their prosperity to Michigan's industrial growth, and were unwilling to deal with the negative consequences of industrialization that the depression era had exposed. Art, in this view, should exist only as a form of escapism. As Constance J. Griffiths tellingly wrote to the editor of the Free Press, 'in these days of super-drabness can we not have some beauty of line, color or form to relieve our sorely harassed souls? ${ }^{\prime 61}$

Quite contrary to the impression given by Rivera's murals, conditions in Detroit industry had been deteriorating under the pressures of the depression era declines in sales, layoffs, increased competition, and the effects of inflation on wages. Ford employees, once famous for being the highest paid industrial workers in the world, often earned less than they had fifteen years before in real terms, were still at the mercy of irregular working contracts and unpredictable layoffs, and enjoyed less labour representation than they had in $1916 .{ }^{62}$ Meanwhile, mechanization had largely removed the need for skilled labourers, and turned work into a painful monotony. Given this, and the widespread industrial discontent in the early years of the I930s, it is hardly surprising that representatives of Detroit's establishment would have expected a mural painted by a communist to have been critical of conditions in the factories. Their responses would have been less notable had this actually been the case.

58 Max Kozloff, 'The Rivera frescoes of modern industry at the Detroit Institute of Arts: proletarian art under capitalist patronage', in Henry A. Millon and Linda Nochlin, Art and architecture in the service of politics (Cambridge, MA, I978), p. 224.

59 Wolfe, The fabulous life of Diego Rivera, p. 307.

61 Detroit Free Press, 2i Mar. I933.

62 On conditions of Ford workers, see Sidney Fine, The automobile under the blue eagle: labor, management and the automobile manufacturing code (Ann Arbor, 1963); Roger Keeran. The Communist Party and the auto workers unions (Bloomington, I980); Nelson Lichtenstein and August Meier, On the line: essays in the history of auto work (Detroit, I976); August Meier and Elliot Rudwick, Black Detroit and the rise of the auto workers (Oxford, I979). 
Similarly, accusations of un-Americanism, instinctively levelled at Rivera's frescoes, were most ironic. There is little doubt that Rivera saw a principal function of his work as contributing to a grand vision of Western continental unity, an attempt to grapple with the idea of Americanism, and strip from it what he saw as encrustations of European culture. In an article entitled 'Listen Americans!', Rivera had cried, 'To hell with your barriers and frontier guards! Listen Americans. Your country is strewn with impossible objects that are neither beautiful nor practical ... Take out your vacuum cleaners and clear away these ornamental excrescences ... Proclaim the aesthetic independence of the American continent! ${ }^{\prime 63}$ Elsewhere, Rivera declared

on the basis of the unity of prehistoric culture preserved faithfully in Latin America, the industrial power of the United States, the raw materials of the southern continent, and the machines of the north, a new era will arise for humanity in which the worker, now in power, will finally bring peace to the world. ${ }^{64}$

When Rivera arrived by boat into New York harbour in December 1931, he pointed to the Equitable Tower in lower Manhattan, and said 'whether the architects know it or not, they were inspired in that design by the same feeling which prompted the ancient people of the Yucatán in the building of their temples ${ }^{65}$ His feeling that a distinctive American aesthetic penetrated continental life from Alaska to the Tierra del Fuego was reflected in the frescoes, in the way in which he used pre-Columbian art to shape his representations of Detroit industry. ${ }^{66}$ As such, and as Rivera himself commented, it was curious to witness

The spectacle of the local prelates of two religious organisations of European origin - one of which openly avows allegiance to a foreign potentate, while the other has its roots deep in alien soil - stirring up the people in 'patriotic' defence of an exotic Renaissance patio against what they decry as an 'un-American invasion', namely the pictoral representation of the basis of their city's existence and the source of its wealth, painted by a direct descendant of aboriginal American stock! ${ }^{67}$

Perhaps Rivera's vision of pan-Americanism was idealistic, certainly it was unrealistic - after all, he drew heavily on the broadest tradition of European art himself - and without doubt his responses were inflammatory, but the frescoes were certainly not un-American, at least in his eyes. Rivera aspired to be a continental Whitman.

Underlying this was the fear expressed by European elites that non-white culture might come to eclipse the Western European legacy in the United States. As a Mexican mestizo, with murals depicting generic representations of four races black, white, red, and yellow, in Rivera's pre-politically correct arrangement - on

63 Cited in Marnham, Dreaming, pp. 254-5. $\quad{ }^{64}$ Azuela, in Helms, ed., Diego Rivera, p. I27.

65 New York Times, I4 Dec. I93I; also cited in Wolfe, The fabulous life of Diego Rivera, p. 276.

66 Barbara Braun, Pre-Columbian art and the post-Columbian world: ancient American sources of modern art (New York, 2000), pp. 215-34; Downs, The Detroit Industry murals, pp. I42-4.

67 Marnham, Dreaming, p. 262. 
an equal footing around the walls of the room, the message was undoubtedly received by WASP elites and white workers as a challenge to their cultural primacy and jobs, respectively. Once again, this might not have caused such a reaction had Detroit not already been so highly attuned to questions of race and ethnicity. The massive expansion of Michigan's industries had led to largescale immigration from Central and Eastern Europe in the first decades of the century and, after immigration laws drastically curtailed this after the First World War, of African Americans from the South. The black population in Detroit trebled during the I920s. A further 25 per cent of Detroit's population was still registered as foreign-born. The fear that the 'white' minority would be swamped by these waves of immigration was the primary reason for the resurgence of the Ku Klux Klan in the I920s, and the racist and anti-Semitic Black Legion, which operated in the I930s, and claimed somewhere between 30 ,ooo and I00,000 members in Michigan and surrounding states. ${ }^{68}$ Mexicans and Mexican Americans were not new, but they were the newest group to draw this white hostility upon them, and one of the chief targets of reactionary forces during the depression years. Migration had been steadily growing from Mexico since the instability of the revolutionary years. Mexicans were omitted from the I924 National Origins Act which established quotas for Asians and Eastern Europeans, and as a proportion of total immigrants they grew rapidly, up to around io per cent of the total by the end of the decade. ${ }^{69}$ Whilst the vast majority settled in the Southwest, the second largest destination was the high-wage industrial areas of the Midwest, with between 6o,00o and 80,00o Mexican migrants recorded in Michigan and Illinois alone by the late I920s, 3,000-4,000 of whom worked for Ford. ${ }^{70}$ As with the rest of US history, stereotypes naturally attached themselves to this newest wave of migration. It was widely argued that Mexicans were untrustworthy, lazy, emotional, and artistic. They were considered notoriously resistant to 'assimilation' and notoriously prone to revolution: in 1934, the ostensibly sympathetic sociologist Emory S. Bogardus observed the Mexican's 'loyalty to his native-soil is deep-seated. He has known so much oppression that he either accepts the status quo without question or else he breaks forth in revolutionary activities.' He also argued that 'Art is a kind of religion to the Mexican ... The Mexican is both literally and figuratively a colorful person. His interest in art is both simple and far-reaching. ${ }^{71}$ These assumed characteristics provided ample justification for excluding Mexican and Mexican American workers from relief and support, for firing them early from jobs, and ultimately

${ }^{68}$ Michael S. Clinansmith, 'The Black Legion: hooded Americanism in Michigan', Michigan History, 55 (Fall 1971), pp. 243-62.

${ }^{69}$ Alejandro Portes and Robert L. Bach, Latin journey: Cuban and Mexican immigrants in the United States (Berkeley, 1985).

${ }^{70}$ Dennis Nodín Valdés, 'Mexican revolutionary nationalism and repatriation during the depression', Mexican Studies/Estudios Mexicanos, 4 (Winter 1988), p. 3; Zaragosa Vargas, Proletarians of the north: a history of Mexican industrial workers in Detroit and the Midwest, I9I7-1933 (Berkeley, I993), pp. 2I, 5 I.

${ }^{71}$ Emory S. Bogardus, The Mexican in the United States (New York, I970; Ist edn, 1934), pp. 17, 65-6. 
for large-scale forced repatriation. The American Federation of Labor had supported quota restrictions on Mexican migrants since 1927. And in their own way, Rivera's murals graphically demonstrated the widespread belief that Mexicans were 'over here' stealing 'American' jobs. As the Mexican consul, Ignacio Batiza, observed 'the Mexican is considered the more foreign of the foreigners of the residents of Michigan'. ${ }^{72}$

Not only was it perplexing that so many refugees from the Mexican revolution (and, latterly, the areas blighted by the Cristero repression) were unthinkingly associated with radicalism, Rivera's primary political activity during his time in Detroit was in co-organizing the Liga de Obreros y Campesinos (League of Workers and Peasants), in co-operation with the consul. ${ }^{73}$ Whilst this group was designed to support Mexican and Mexican American workers in a wide range of ways, its chief role quickly became supporting individuals and families who sought to return to the revolutionary fatherland, often in close co-operation with the US state apparatus of immigration and justice. Rivera provided money, logistical support, and helped to smooth the passage for many returnees who had spent so long in the United States they were considered unwelcome agringados ('Americanized ones') by locals. As time went on, Rivera came to doubt the wisdom of universal repatriation. But in practice, whilst it was seen this way by no one at the time, Rivera had spent much of his energy aiding and abetting the nativist agenda of freeing up 'American' jobs for white people. Moreover, the chief critic of the Liga was the CPUSA's International Labor Defense, restating their claims that the 'renegade' Rivera was opportunistically aiding the capitalist classes in their agenda for enrichment and aggrandizement. ${ }^{\mathbf{7 4}}$

Henry Ford had a doubly contentious position in the context of these questions of race relations. Famously, Ford hired many more black employees than other automobile companies and in the rgios was one of the nation's foremost advocates of Americanization and assimilation of foreign workers. One Mexican worker, José Robles, went to work for Ford in I9I7, and by the end of the I920s proudly told an anthropologist that as well as being a thirty-second and a half degree Mason, 'I am now following American customs in everything that I can. I married a German girl in Detroit in the Baptist church and before the Justice of the Peace.' 'A very strange thing happens to me', he recorded. 'I eat at home and I digest well but when I go to the homes of relatives and they give me Mexican dishes I am sick at night. ${ }^{, 75}$ Ford was the last major employer in Michigan to cave in to pressure to fire all non-naturalized workers during the wave of anti-Mexican hostility that arose during the depression. Ford's supporters took his policies as a sign of racial progressiveness; opponents alleged that minorities were hired either to do the jobs 'white' Americans were not prepared

72 Cited in Valdés, 'Mexican revolutionary nationalism', p. I I.

73 Francisco E. Balderrama and Raymond Rodríguez, Decade of betrayal: Mexican repatriation in the I93os (Alburquerque, 2006), p. I73. $\quad{ }^{74}$ Vargas, Proletarians of the north, pp. $185^{-6 .}$

75 Cited in Manuel Gamio, The Mexican immigrant: his life story (Chicago, I93I), pp. 227-9. 
for, or to act as strikebreakers. Unlike Rivera's painting, where workers of all colours toil together in the factories, minorities were more often than not segregated into specific areas of the plant, such as the foundries. In a sense, of course, Rivera could not have won this debate. Had he painted the murals in actual representation of conditions in Detroit's factories, he would have been accused of inciting racial hatred; as it stood, he could be criticized for advocating integration and miscegenation.

In a similar manner, the androgyny of the autochthonous racial figures was taken as a challenge to traditional formations of gender. It is perhaps unfair that Rivera is today seen as a bête noir for female equality; but this contemporary image undoubtedly contrasts with the picture conjured by the anti-communist audience of the time. One writer for the Free Press, imagining a fictitious visitor ('he', of course), described how

In one panel, grain is shown pouring from a woman's arms. In another a woman cradles the fruits of the trees in her arms. But here, too, the spectator sees grotesquery, even repulsiveness. The artist, he vaguely understands, has attempted to picture for him the creation of all things. There is something embryonic about the entire eastern wall of the court. $^{76}$

'Instead of painting the fine type of business girls one sees in the office buildings', Eugene Paulus argued, Rivera 'painted houris and streetwalkers. ${ }^{, 77}$ As such, George Derry combined both racial and gendered anxieties when he asked, rhetorically, 'Will the women of Detroit feel flattered when they realize that they are embodied in the female with the hard, masculine, unsexed face, ecstatically staring for hope and help across the panel to the languorous and grossly sensual Asiatic sister on the right? ${ }^{78}$

Ultimately, and unlike other pieces by Rivera, the Detroit Industry murals cannot fairly be criticized for being doctrinaire or calculatingly subversive. As has been widely noted, Detroit Industry was notably absent of the revolutionary sloganeering normally found in Rivera's work and, unlike the later Rockefeller mural, included no communist heroes or contentious statements about the revolution to come. In fact, the only slogan that made it into the Detroit Industry murals was partially obscured and tucked into a workers' hat on the southern wall. Reading 'We want', it was a reference to the anti-prohibition war-cry popularized at the American Legion's I93I convention (itself held in Detroit), chanted by drunken delegates to a horrified President Hoover: 'We Want Beer.'

This distinction between Rivera's stated allegiance and the content of the murals was, arguably, what saved them from whitewashing. Rolling out the only senior employee of the Institute who spoke English as a first language, E. P. Richardson, whose father and brother were Episcopalian priests, the Institute's rebuttal campaign revolved around pandering to the conservatism of

76 Detroit Free Press, i7 Mar. I933.

78 Lochbiler, 'Battle of the Garden Court'.

77 Detroit News, 2I Mar. I933. 
the audience, and separating the murals from the image of Red Rivera. The head of the DIA, William Valentiner, recollected, 'Richardson spent days defending the murals in his calm and convincing manner, standing on the edge of the fountain because there was no space on the floor. ${ }^{79}$ Valentiner reminded the press that 'the amount of tax-payer's money invested in symbols, emblems, and decorations of the Christian faith far exceeds any other'. ${ }^{80}$ Clyde H. Burroughs, secretary of the Arts Commission, flatly denied there was any association of the nativity in the Vaccination scene. 'Anybody who can see even a hint of the Nativity in the murals can see ghosts in the moonlight and demons in the clouds', he said ${ }^{81}$ Fred L. Black of the People's Museum Association said 'Mr. Rivera has pictured most perfectly the essence of the indomitable industrialism which has made Detroit famous all over the world. ${ }^{92}$ A huge sign was attached to the far wall of the Garden Room, reading:

Rivera's politics and his publicity seeking are detestable. But let's get the record straight on what he did here. He came from Mexico to Detroit, thought our mass production industies [sic] and our technology wonderful and very exciting, painted them as one of the great achievements of the twentieth century. This came just after the debunking twenties when our own artists and writers had found nothing worthwhile in America and worst of all in America was the Middle West. Rivera saw and painted the significance of Detroit as a world city. If we are proud of this city's achievements, we should be proud of these paintings and not lose our heads over what Rivera is doing in Mexico today. ${ }^{83}$

In the end, then, municipal pride trumped nationalism.

What Detroit was really debating in the argument over the Detroit Industry murals was the basis of its own social relations. Complaints reflected the priorities and concerns of the vested interests involved, themselves stemming from the tensions released by the unprecedented and largely uncontrolled growth of the city in the first two decades of the twentieth century. They reflected what Detroit anti-communists expected to see in the murals of a communist, and thus said more about their understandings of communism than they did about the murals themselves.

In a sense, this many-sided social reaction became the artwork. The combination of detail, accessibility, and narrative in Rivera's work ensured that individuals would see themselves and the world around them in the murals. (Sometimes quite literally, for Rivera used many Ford workers and Detroit residents as models for people in the murals.) If anything, Detroit Industry presaged the philosophy of later twentieth-century art, where the work would be designed to transcend itself, slip from the wall, coming to rest at a point between viewer and object. Even the supposed 'aesthetic conflict' between the Mexican mural work and its rococo surroundings forms part of this effect. The clash of competing heritages, a high modernist portrait in a sixteenth-century gilt-edged frame, as it

79 Margaret Sterne, The passionate eye: the life of William R. Valentiner (Detroit, I980), p. 201.

80 Detroit Free Press, 2 I Mar. I933. $\quad{ }^{81}$ Ibid., I7 Mar. I933. ${ }_{82}^{82}$ Ibid., 2 I Mar. I933.

83 Downs, The Detroit Industry murals, pp. I76, I80. 
were, is a fitting depiction of the magpie culture that was, and remains, Detroit and the United States.

There was a final twist in the story of the fresco scandal, one that suggests an extra component in the mechanics of anti-communist protest. Rivera had believed the original, anonymous defamatory accusations had come from the designer of the stained glass windows used in Father Coughlin's Royal Oak church. ${ }^{84}$ But Rivera's memory was sketchy at times, and he was prone to exaggeration and poetic licence even when he was not mistaken. (For a start, Coughlin would have struggled to 'honour' him daily, since his radio show went out weekly.) When art historians investigated the anonymous letter to the editor of the Free Press that had sparked off the scandal, it turned out that it had been written by a sympathetic reporter, worried about poor attendance and low finances at the Institute. ${ }^{85}$ George Pierrot of the Institute had taken up the allegations, and invited clergymen to view the murals, knowing their reaction would create a sensation and correctly guessing that the result would be increased custom. ${ }^{86}$ In 1934, in the wake of the highest attendance figures in the history of the Institute, the budget for the DIA was raised to $\$$ I 30 ,ooo.

\section{V}

In 1933, Detroit saw the unveiling of probably the greatest work of fine art in its history, a work which marked an artistic and psychological watershed for its creator. Rivera recalled his year in Detroit as 'perhaps the best and most fruitful period of my life.${ }^{87}$ Yet, despite this, it took a long time before the visiting communists were thought about in anything other than terms of scandal. Rivera and Kahlo continued on to New York after Detroit, where the anti-communist attacks proved even more venomous, culminating in the destruction of Rivera's murals at the Rockefeller Center. Reluctantly on the part of Rivera, and happily for Kahlo, the two returned to Mexico at the end of 1933, ensuring that little of their work can now be found in the United States.

Still, Rivera left a legacy for American artists in the I930s. $^{88}$ On the same day that Rockefeller decided to cancel Rivera's RCA contract, American artist George Biddle wrote to President Roosevelt. Noting that 'The Mexican artists have produced the greatest national school of mural painting since the Italian Renaissance' and quoting Rivera that this could not have happened without

${ }^{84}$ Rivera, $M A M L$, p. i 8.

85 George F. Pierrot, 'Frescoes and finance at the DIA', The Dearborn Herald, 8 (Fall i979).

86 Downs, The Detroit Industry murals, p. I78.

87 Rivera, $P O A$, p. 18.

88 For a general discussion of the New Deal murals and Rivera's legacy, see Belisario Contreras, Tradition and innovation in New Deal art (London, I983); Karal Ann Marling, Wall-to-wall America: a cultural history of Post Office murals in the Great Depression (Minneapolis, I982); Barbara Melosh, Engendering culture: manhood and womanhood in New Deal public art and theater (Washington, DC, I99I); Richard D. McKinzie, The New Deal for artists (Princeton, I973); Francis V. O'Connor, 'The influence of Diego Rivera on the arts of the United States during the r93os and after', in Helms, ed., Diego Rivera; Francis V. O'Connor, ed., Art for the millions (Boston, MA, I973). 
government support, Biddle urged the New Deal administration to provide patronage to struggling artists in the depression era ${ }^{89}$ This letter, ultimately, helped lead to the Public Works of Art Project (PWAP), the Department of Treasury's Section of Painting and Sculpture, and the mural schemes sponsored by the Federal Arts Project of the Works Progress Administration (WPA). In the end, the Roosevelt administration sponsored the production of over 2,00o murals during the I93os, replacing the private sector as chief source of artistic patronage.

But if FDR was inspired by the example of Mexican murals in developing his cultural programmes, he was less impressed by the reaction of the American public to Rivera's work. Roosevelt wrote to Biddle, 'I can't have a lot of young enthusiasts painting Lenin's head on the Justice Building. They all think you're communists. Remember my position. Please! ${ }^{\prime 90}$ So whilst the New Deal programmes were in part the product of what Philip Evergood called 'Mexican pollen which has been wafted northward on the breeze', the New Deal murals conspicuously avoid references to Rivera or his industrial themes ${ }^{91}$ Early on, decentralization in the PWAP led to a scandal that echoed Rivera's experiences. In the Coit Tower murals, produced in 1934 in San Francisco, Clifford Wight and other muralists created works 'awash in Red symbolism', and 'strikingly reminiscent of Rivera's Detroit frescoes'. ${ }^{92}$ Bernard Zakheim's Library included a picture of a man reading a newspaper headline reading 'Destruction of Rivera Fresco'. But such mistakes were rarely repeated, and New Deal administrator Edward Bruce was largely successful in his stated goal of stopping the 'Mexican invasion at the border'. ${ }^{93}$ After 1934, through the application of assessment criteria based around flexible concepts of 'community', 'taste', 'thematic relevance', and historical 'fact', federally sponsored murals were largely divorced from controversial thematic content, and steered towards uncritical depictions of 'safe' history, often agrarianism and pastoral scenes. Ironically, the need to bend to public sensibilities was felt more strongly in projects sponsored by the federal government than they had been when paid for by private capital. Even in Detroit, many works avoided the subject of industrialization. The post office in Dearborn, Ford's home town, chose to depict a traditional tavern on a stagecoach route, and similar pressures pushed the commissioners of a mural in Detroit's Lincoln Park away from any reference to Ford, or transport at all. ${ }^{94}$

Nevertheless, the WPA projects were never able completely to escape accusations of communistic tendencies, and were curtailed during the Second World

89 George Biddle, An American artist's life (Boston, I939), p. 268.

90 Cited in Contreras, Tradition and innovation, p. 51; Biddle's recollection also in Marling, Wallto-wall America, p. 42.

91 Philip Evergood, 'Concerning mural painting', in O'Connor, ed., Art for the millions, p. 49.

92 Marling, Wall-to-wall America, p. 46; Contreras, Tradition and innovation, p. 46.

93 Cited in McKinzie, New Deal for artists, p. 57.

94 Barbara Melosh has written, 'The absence of automobile manufacture in public art in the very heart of Ford and General Motors territory speaks volumes about Section cultural policy.' Melosh, Engendering culture, p. I2I. 
War when Roosevelt's priorities fell elsewhere. The mistaken assumptions that governed the anti-communist reaction to Rivera's work in Detroit may help to explain why the label of communism stuck even when so much effort was made to excise radical content from the New Deal mural projects. ${ }^{95}$

With the decisive movement of American art toward the inner life of Abstract Expressionism in the post-war years, the remaining legacy of Rivera's work in the United States was lost. Rivera's work was not featured in a major show at the DIA until I978. The fact that Rivera's murals were a panegyric to the Detroit industrial establishment and effectively brushed over the violence and poverty experienced by workers in the depression-era city; the fact that Rivera was denounced by the Communist Party as a stooge of millionaires and a renegade; the fact that Rivera was vocally calling for the development of a continental American nationalism against all-pervasive, European influences; the fact that Detroit's most powerful family, the Fords, fully supported and funded his work - all this signally failed to alter attitudes toward this foreign communist and his murals. In the end, opposition to the Detroit Industry frescoes was fuelled by a sense of civility and decorum under threat, by religiosity, anti-modernism, mistrust, and fear of Detroit's own industrial growth, by an aggressive prudishness, and by a host of other concerns mostly unrelated to the actual content of the murals. In this case, industrial, and firmly anti-communist, modernists like Ford had more in common with revolutionary ideologues than the cream of the haute bourgeoisie.

Laying the validity of these aesthetic and moral viewpoints to one side, such anti-communist reactions had little to do with high politics, less to do with the incipient threat posed by Stalinism or Soviet Russia, and nothing at all to do with the communist espionage networks that were forming in the early I930s, as avowedly important as these things were to other anti-communists, elsewhere. Whilst we must pay deserved attention to these latter elements in understanding the history of anti-communism, it is important not to neglect the cultural component of the history of this 'persuasion' in any comprehensive study. The debates and disagreements that took place within this rhetoric of anti-communism are not so much full stops, as places to start.

${ }^{95}$ Compare, for example the reactions to Rockwell Kent's Puerto Rican Post Office mural, or the NCWC reaction to Maurice Sterne's Cruelty. Contreras, Tradition and innovation, pp. $5{ }^{\mathrm{I}-5}$. 